\title{
Franciszek Kaźmierczyk
}

Dr inż.

Instytut Techniczny Wojsk Lotniczych, Warszawa, Zakład Lotniskowy

\section{Piotr Nita}

Prof. dr hab. inż.

Instytut Techniczny Wojsk Lotniczych, Warszawa, Zakład Lotniskowy

piotr.nita@itwl.pl

DOI: 10.35117/A_ENG_18_12_03

\section{Airfield pavements on the lake ice sheets}

\begin{abstract}
The article presents theoretical notions concerning possibility of using the lake ice sheets for performing potential flight operations. Theoretical discourse was verified ,in situ" on national reservoirs in the warminsko- mazurski region. Presented complex of issues and final conclusions allow applying aforementioned areas for flight operations in event of force majeure.
\end{abstract}

Keywords: Lake ice sheet; Flight operation; Hertz equation

\section{Introduction}

The geographical location of Poland subject to the influence of the continental and Atlantic climate is very diverse, however, this location does not exclude limited time and space, the use of ice sheets forming on lakes as a surface for conducting air operations. Landings on ice sheets can be used by state aviation while fulfilling their mission or during natural disasters and other events in justified situations. Air operations performed on ice sheets are possible, however, for relatively light aircraft with rather traditional types of propulsion. Heavy aircraft require thicker coatings with more stable climatic conditions. Temperature fluctuations cause unevenness in the formation of ice sheets mainly on lakes.

The beginning of the ice sheets on the lakes of our country can be observed already in the third decade of November and lasts until the first decade of April. The average duration of the ice sheets in our conditions can be about 90 days. The thickness of the ice sheets is on average from 30 to $40 \mathrm{~cm}$, and the maximum observed thickness is from 60 to $80 \mathrm{~cm}$. The beginning of the ice sheet formation and the time of its deposition depends on the local conditions and also on: the depth of the reservoir, the surface of the basin, the height of the banks and their afforestation, etc. The formation of the ice sheets on the lake's bodies is closely related to the thermal circulation of waters. The advantage of these coatings is that they are even and do not require large amounts of preparatory work.

\section{Construction and structure of the ice sheets}

The ice sheets crystallize in the hexagonal system. Optically ice crystals are uniaxial, with the optical axis identical to the axis of symmetry. Ice on the lakes consists of single, irregular prisms directed vertically to the surface of the water surface. The posts created to consist of thin plates, each of which is a crystal. The ice sheets do not form simultaneously on the entire surface of the water reservoir but starts in zones where solid crystalline nuclei have formed, which, when they are growing together, form a thin ice sheets with a tendency to further thicken it. The specific weight of the ice is $920 \mathrm{~kg} / \mathrm{m}^{3}$, the ice weight (free of pores) is 917 $\mathrm{kg} / \mathrm{m}^{3}$. The density of ice formed in natural conditions ranges from $910.8 \mathrm{~kg} / \mathrm{m}^{3}$ to 911.5 $\mathrm{kg} / \mathrm{m}^{3}$. For practical purposes, thermal conductivity is assumed to be equal to 1.5 to 3.0 
$\mathrm{kcal} / \mathrm{h}$. The ice elasticity is insignificant and according to [1] does not exceed $0.08 \mathrm{MPa}$. The coefficient of ice elasticity depends on ice-cream structure, the degree of water pollution, air temperature and load method. The range of this coefficient is assumed (from 9000 to 115000 $\mathrm{kg} / \mathrm{m}^{2}$ ), i.e. 0.088 to $1.128 \mathrm{MPa}$. It is believed that in the case of the ice sheets it is more correct to adopt, instead of the elastic modulus of ice, a module of total deformation, i.e. elastic and plastic deformation. The strength characteristics of ice are determined by its structure, density, and degree of possible salinity of the water body and duration of stable temperature. Temperature changes can cause even a double change in its strength.

\section{Permissible load and required thickness of the ice sheets}

It can be assumed that the ice sheets are a structure that under the influence of external load behaves like a resilient plate resting on the elastic base. The theory of bearing capacity of ice sheets was used for the first time by H. Hertz [3], its solutions have been used until now. The experience of other researchers [2],[5],[7] showed that the sagging of the ice sheets in the initial period increases in proportion to the load size in accordance with the laws of elasticity theory. However, there will be scratches in the ice shell, changes these laws and the ice sheet is already working as a plastic-elastic board. The first crack in the ice sheet does not mean that the critical condition of the coating is exceeded. The critical condition occurs at the moment when many cracks appear in the shell after their occurrence, the coating is destroyed. Practical measurements [4] showed that the first radial cracks in the ice sheets arise after its load constituting $2 / 3$ of the destructive load. The differential equation presented by Hertz [3] regarding the deflection of an infinitely large elastic plate, which can be identified with a floating ice sheets, is still a theoretical basis for solutions of elastic plates on a flexible substrate. The differential equation for an ice plate with a specific gravity $\gamma_{\mathbf{p}}$, thickness $\mathbf{h}$, floating in the water of specific gravity $\gamma_{\mathrm{s}}$ subjected to a concentrated load, can be presented in the form:

$$
\Delta^{2}\left(\Delta^{2} \mathrm{w}\right)=\left(\frac{d^{2}}{d r^{2}}+\frac{d}{r d r}\right)\left(\frac{d^{2} w}{d r^{2}}+\frac{d w}{r d r}\right)=\frac{p(x, t)}{D}
$$

where: $r$ - the deflection radius of the sheet from the center of the load,

$\mathrm{w}$ - deflection of the ice sheet,

$\mathrm{p}(\mathrm{x}, \mathrm{t})$ - load on the ice sheet,

$\gamma_{\mathrm{s}}-$ specific gravity of water,

$\mathrm{h}$ - thickness of the ice sheet,

$\mu$ - Poisson's ratio,

$\mathrm{D}$ - sheet stiffness according to the pattern (2).

$$
\mathrm{D}=\frac{E h^{3}}{12\left(1-\mu^{2}\right)}
$$

The essence of the solution lies in the fact that the floating ice sheet loaded with force $\mathrm{P}$ exerts pressure on the water of $\mathbf{p}=\gamma_{\mathbf{p}} \cdot \mathbf{h}$ with specific gravity $\gamma_{\mathbf{s}}$ greater than the specific gravity of the plate $\gamma_{\mathrm{p}}$, then the water reaction to the plate follows $\mathbf{p}=\gamma_{\mathbf{s}} \mathbf{w}$.

In the middle load point, the largest positive radial and circumferential bending moments can be written as dependencies: 


$$
\sigma_{\mathrm{r}}=\sigma_{\mathrm{t}}=1,1(1+\mu)\left(\log \frac{l}{a}+0,26\right) \frac{P}{h^{2}}
$$

where:

1 - radius of relative stiffness of the plate in accordance with the formula (4)

$\mathrm{k}$ - the substrate response factor, in the case of the ice sheets - the water pressure per unit area, per unit of deflection,

$\mathrm{P}$ - the size of the applied load,

a - radius of the load contact surface.

$$
1=\sqrt[4]{\frac{E h^{3}}{12\left(1-\mu^{2}\right) k}}
$$

The largest negative radial bending moment occurs at a distance of $\mathrm{r}=1.91$ from the center of the load and is approximately $\mathrm{M}_{\mathrm{r}}=0,02 \mathrm{P}$ per unit of length. The increase in the external load causes that the bending stresses in the plate reach values close to the bending ice strength values. A further increase in the load causes that the length and the number of radial cracks in the lower zone of the plate increases, on the upper surface a peripheral break caused by stretching is formed. In this state, the strength limit of the ice sheet is reached. The bending moment per unit length is:

$$
\mathrm{M}=\frac{R_{z}}{6} \mathrm{~h}^{2}
$$

The theoretical destructive load in the range of the practical radius of the distribution "a" can be determined from dependence:

$$
\mathrm{P}_{\mathrm{o}}=3,3 \pi\left(1-\frac{3 a}{2 l}\right) \mathrm{M}_{0} \quad \text { dla } \quad 0,05<\frac{a}{l}<1
$$

where:

$\mathrm{M}_{\mathrm{o}}$ - value of the limit bending moment per unit length.

The analysis of various cases of ice load and their practical verification carried out by [7] showed that for cases where the radius of the load distribution "a" is greater than the thickness of the ice sheets, then its permissible load can be determined from dependence:

$$
\mathrm{P}_{0}=\mathrm{R}_{\mathrm{z}} \cdot \mathrm{h}^{2}
$$

Another form of sagging of the ice sheets suggests [10] and believes that the deflection of this coating can be illustrated in the form of a logarithmic curve and expressed in the form of an equation:

where:

$$
\mathrm{w}=\mathrm{w}_{0} \cdot \mathrm{e}^{-\mathrm{kx}}
$$

$\mathrm{w}$ - deflection of the coating under load,

$\mathrm{k}$ - the deflection coefficient is usually taken as equal to 0.1 per unit of length.

Comparing the volume of displaced water to the load size and considering dependence (8), the author proposes to distribute the load on a rectangular surface and derive dependence: 


$$
\mathrm{P}=\mathrm{P}_{0}\left(1+\frac{k S}{2 \pi}+\frac{k^{2} F}{2 \pi}\right)
$$

where:

$\mathrm{S}$ i F - means respectively the perimeter and the surface on which the load has been distributed,

$\mathrm{P}_{0}-$ load, the size of which causes the displacement of water of a specific volume.

$\Theta$ - ice temperature.

After the correction was introduced due to the temperature and appropriate substitutions, a formula for the permissible load on the ice sheets was obtained:

$$
P_{\text {dop }}=10 h^{2}(1+\Theta)(1+0,2 S+0,002 F)
$$

The classic Hertz solution and the authors' suggestions presented above [1],[7],[9] do not exhaust all possible issues related to determining the strength of ice sheets. The deflections of the ice sheets are shown in Figs. 1 and 2. In order to determine the relationship between ice strength and bending temperature, air tests were made on beams cut out of the ice.

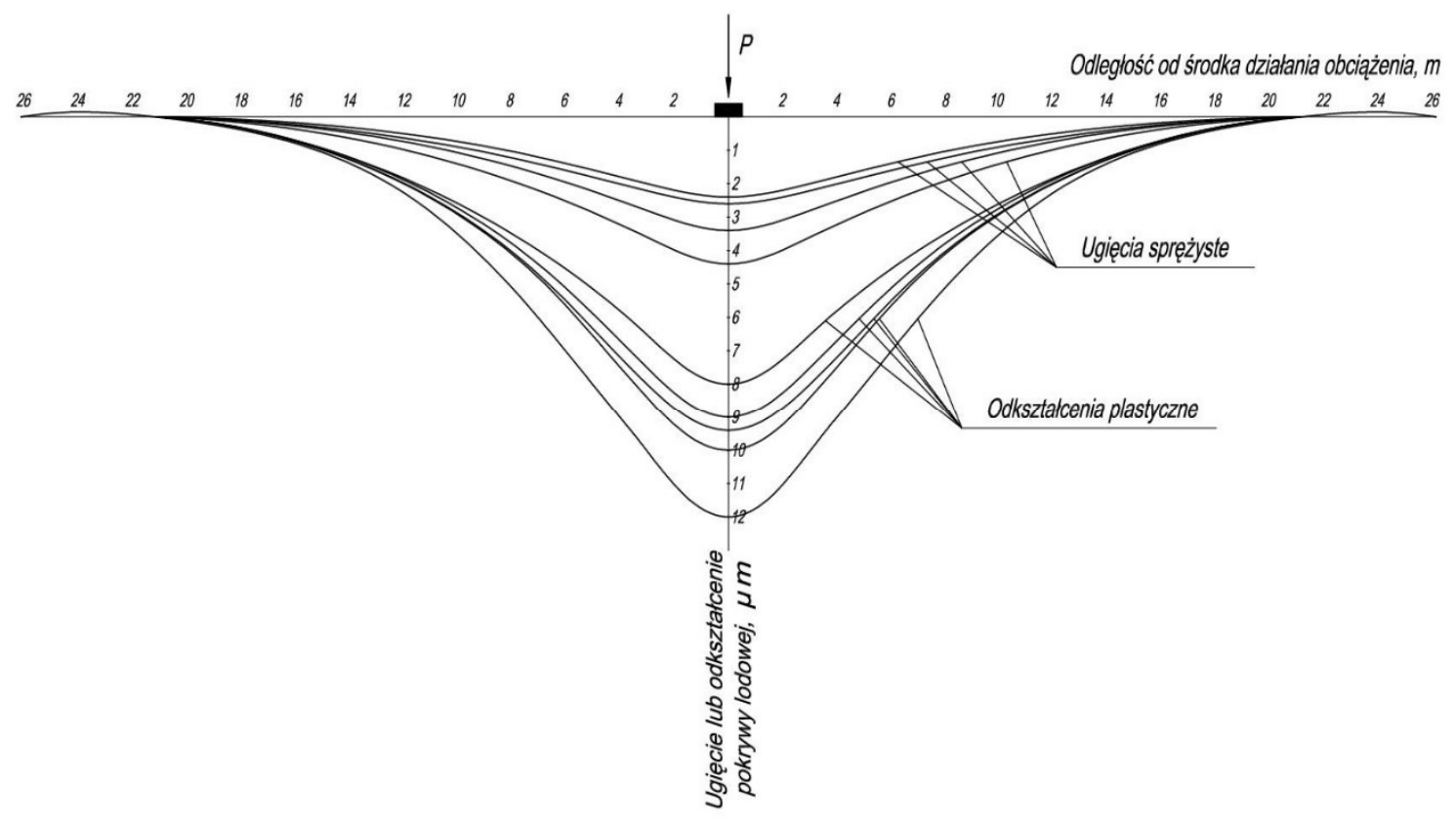

1. Chart of the largest elastic deflections and plastic deformations of the ice coating 


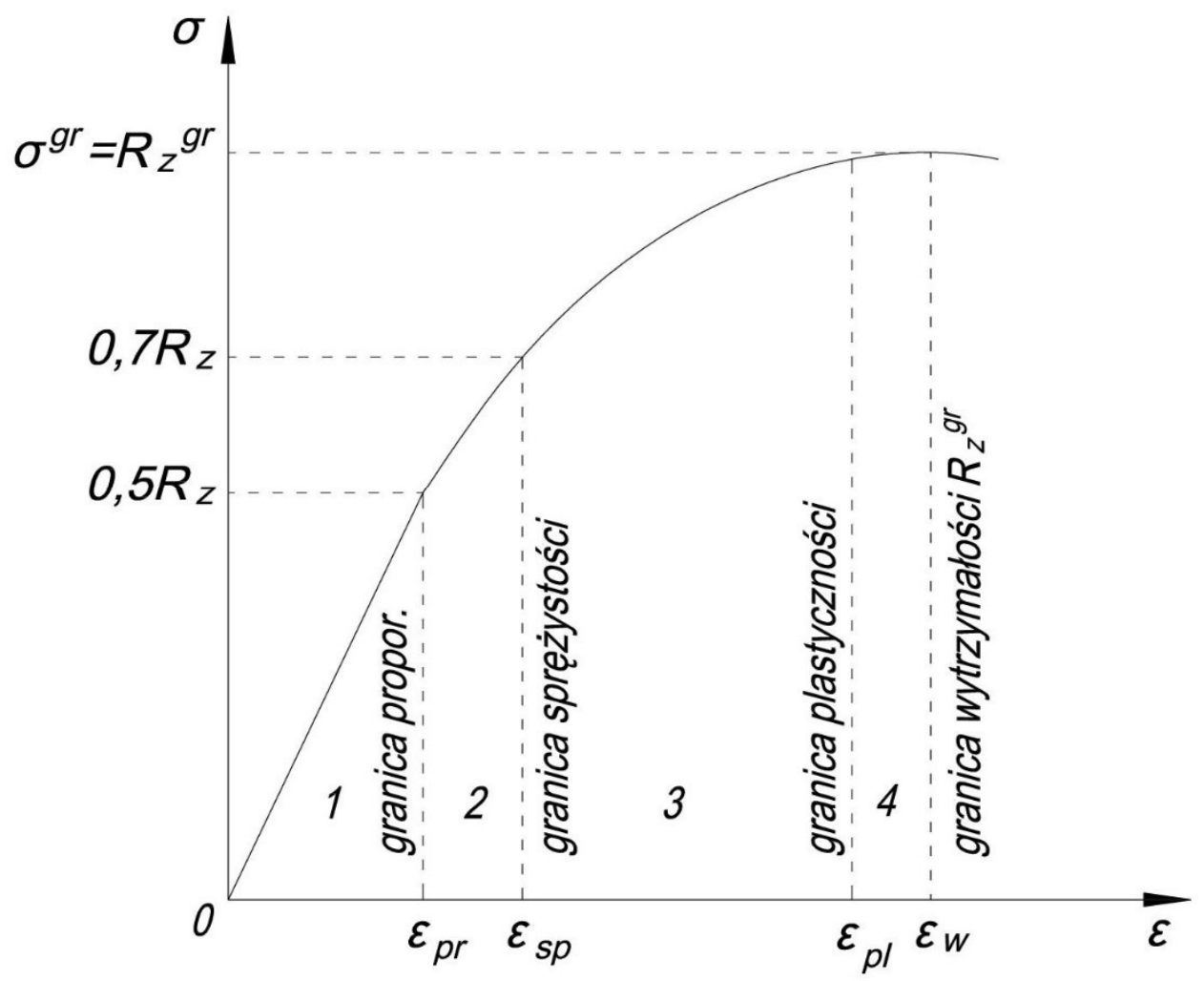

2. Areas of structural changes in the ice coating

The exemplary results with reference to the condition of the ice sheets are shown in Table 1, and in the graphical form in Fig.3. 


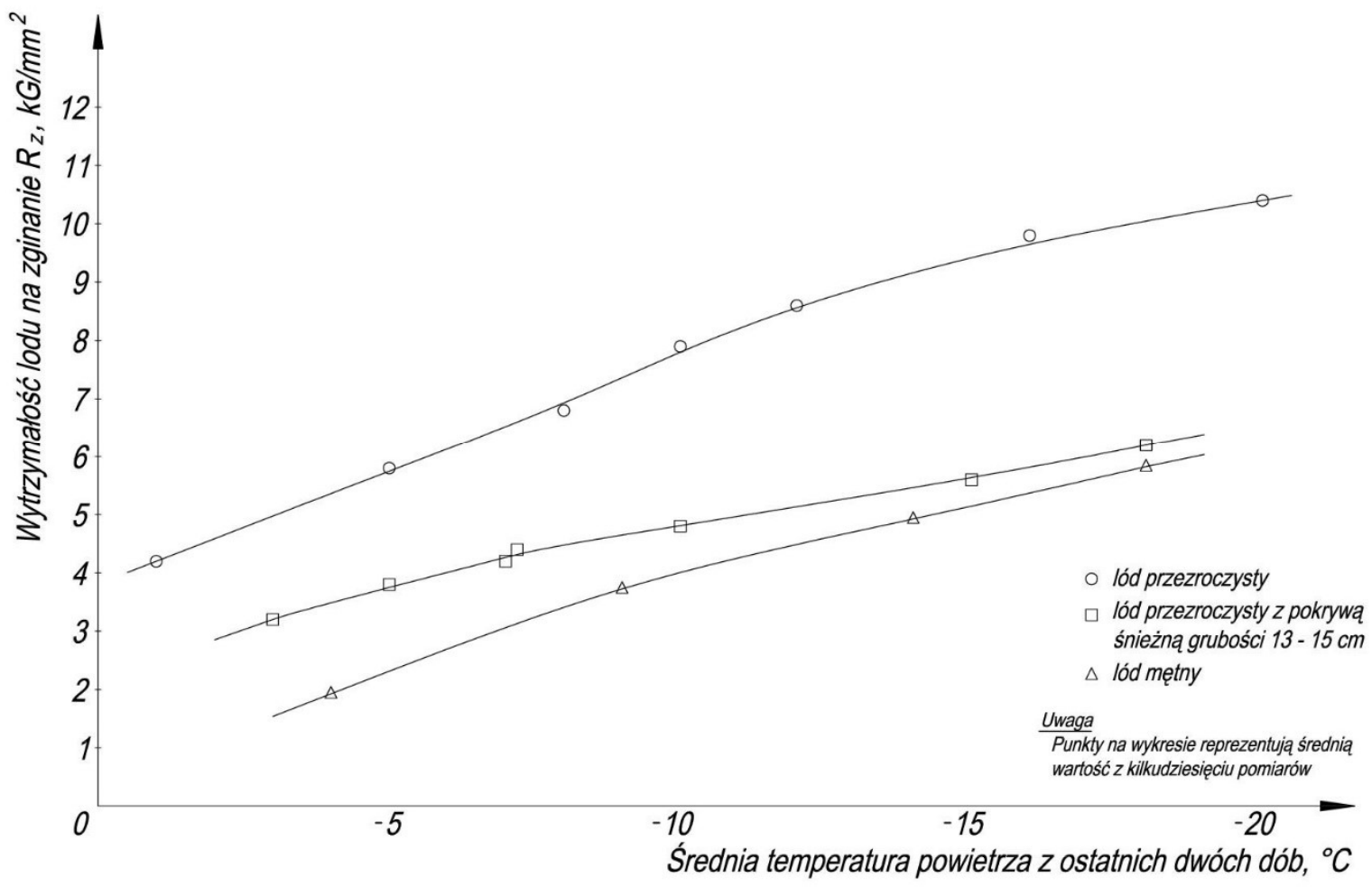

3. Graph of dependence between bending ice strength and air temperature

Tab. 1. Selected results of ice strength tests depending on the ambient temperature and condition of the ice coating

\begin{tabular}{|c|c|c|c|c|}
\hline Type of ice & $\begin{array}{c}\text { Thickness of ice } \\
\text { cover } \mathrm{h}[\mathrm{cm}]\end{array}$ & $\begin{array}{l}\text { The average air } \\
\text { temperature } \\
\text { from the last } \\
\text { three days } \\
\text { before the study } \\
\text { in }\left[{ }^{0} \mathrm{C}\right]\end{array}$ & $\begin{array}{l}\text { Number } \\
\text { of tests }\end{array}$ & $\begin{array}{c}\text { Medium bending } \\
\text { strength of ice coating } \\
\text { samples in }[\mathrm{MPa}] \text { in } \\
{\left[\mathrm{N} / \mathrm{m}^{2}\right]}\end{array}$ \\
\hline Transparent ice & $\begin{array}{l}28,0-30,0 \\
28,0-30,0 \\
28,0-30,0 \\
28,0-30,0 \\
30,0-32,0 \\
30,0-32,0 \\
30,0-32,0\end{array}$ & $\begin{array}{l}-1 \\
-5 \\
-8 \\
-10 \\
-12 \\
-16 \\
-20\end{array}$ & $\begin{array}{l}20 \\
20 \\
16 \\
16 \\
48 \\
20 \\
16\end{array}$ & $\begin{array}{rr}4,14 & (405909) \\
5,73 & (561921) \\
6,84 & (670775) \\
7,92 & (776687) \\
8,61 & (844352) \\
9,89 & (969878) \\
10,39 & (1018911)\end{array}$ \\
\hline $\begin{array}{l}\text { Transparent ice } \\
\text { with a snow } \\
\text { cover of } 13.0- \\
15.0 \mathrm{~cm} \text { on it }\end{array}$ & $\begin{array}{l}13,0-16,0 \\
13,0-16,0 \\
13,0-16,0 \\
20,0-25,0 \\
20,0-25,0 \\
20,0-25,0\end{array}$ & $\begin{array}{l}-3 \\
-5 \\
-7 \\
-10 \\
-15 \\
-18\end{array}$ & $\begin{array}{c}21 \\
212 \\
21 \\
20 \\
20 \\
5\end{array}$ & $\begin{array}{cc}3,11 & (304987) \\
3,88 & (380498) \\
4,15 & (406976) \\
4,86 & (476603) \\
5,62 & (551134) \\
6,15 & (603109)\end{array}$ \\
\hline
\end{tabular}




\begin{tabular}{|l|l|l|l|l|}
\hline Vague ice & $28,0-32,0$ & -4 & 10 & $1,98(194172)$ \\
& $28,0-32,0$ & -9 & 10 & $3,78(370691)$ \\
& $28,0-32,0$ & -14 & 10 & $4,98(488371)$ \\
& $28,0-32,0$ & -18 & 10 & $5,82(570747)$ \\
\hline
\end{tabular}

\section{Evaluation of the elastic properties of the ice sheets}

The ice sheets deflection equation from the concentrated load acc. Hertz can be saved in the form:

$$
\mathrm{w}(\mathrm{x})=\frac{\theta}{4 l^{2}} \cdot \mathrm{Z}_{3}(\mathrm{x})
$$

where:

$\mathrm{w}(\mathrm{x})$ - deflection of the ice coating at a distance $\mathrm{x}$ from the place of load application,

$\mathrm{Q}$ - load on the ice coating,

1 - radius of relative ice stiffness,

$\mathrm{Z}_{3}$ - real variable function, determined from dependencies (16).

The greatest deflection of the sheet under load occurs at the point $\mathrm{x}=0$ and $\mathrm{Z}_{3}=0.5$, they can be determined from the dependence (12):

$$
\mathrm{w}(\mathrm{x})=\frac{\theta}{8 l^{2}}
$$

Author's research [4] made on real ice coatings during trials showed that: its deflection amounts to $0.004 \mathrm{~cm}$ for every $1000 \mathrm{~kg}$ of generated load, the radius of relative rigidity of the ice coating is then $5.27 \mathrm{~m}$. Assuming Poisson's ratio $\mu=0.33$, and the transformation of the formula (4) and the acceptance of $1=5.27$, you can determine the elasticity coefficient of ice, the average value of which was determined at $\mathrm{E}=32600 \mathrm{~kg} / \mathrm{cm}^{2}(0.32 \mathrm{MPa})$ and this result is comparable to the results obtained by other researchers [6],[8]. Analyzing the deflection of the ice sheet under the load evenly distributed on its surface, it should be borne in mind that, as in the case of slabs resting on other warps, it will depend on the weight of the airplane and the geometric arrangement of the wheels in the main leg. It can be assumed that the load is evenly distributed on a circular surface with a small radius $r=a$ (compared to an infinitely large ice sheet). We then distinguish two areas of load impact: internal when $r \leq a$ and external when $r$ $\geq a$. Boundary conditions for both these areas will be different. On a circle with radius $r=a$, transient conditions are met, which express the equality of deflections and their derivatives up to the 3rd degree. Bearing the above in mind, equilibrium equations for the deflection "w" corresponding to these distinguished areas were established:

- for the internal area:

$$
\mathrm{w}_{\mathrm{w}}(\mathrm{x})=\mathrm{q}\left[1+\mathrm{C}_{1} \cdot \mathrm{Z}_{1}(\mathrm{x})+\mathrm{C}_{2} \cdot \mathrm{Z}_{2}(\mathrm{x})\right]
$$

- for the outer area:

$$
\mathrm{w}_{\mathrm{z}}(\mathrm{x})=\mathrm{q}\left[\mathrm{C}_{3} \mathrm{Z}_{3}(\mathrm{x})+\mathrm{C}_{4}(\mathrm{x})\right]
$$

where: $\mathrm{C}_{1}-\mathrm{C}_{4}$ integration constants expressed by $\alpha=\frac{a}{l}$ 


$$
\begin{array}{ll}
\mathrm{C}_{1}=-\frac{K_{1}(\alpha) Z_{3}^{\wedge}(\alpha)+K_{2} Z_{4}^{\wedge}(\alpha)}{K_{1}^{2}(\alpha)+K_{2}^{2}(\alpha)} ; & \mathrm{C}_{2}=-\frac{K_{2}(\alpha) Z_{3}^{\wedge}(\alpha)-K_{1}(\alpha) Z_{4}^{\wedge}(\alpha)}{K_{1}^{2}(\alpha)+K_{2}^{2}(\alpha)} \\
\mathrm{C}_{3}=\frac{-K_{1}(\alpha) Z_{1}^{\wedge}(\alpha)-K_{2}(\alpha) Z_{2}^{\wedge}(\alpha)}{K_{1}^{2}(\alpha)+K_{2}^{2}(\alpha)} ; & \mathrm{C}_{4}=\frac{-K_{2}(\alpha) Z_{1}^{\wedge}(\alpha)+K_{1}(\alpha) Z_{2}^{\wedge}(\alpha)}{K_{1}^{2}(\alpha)+K_{2}^{2}(\alpha)}
\end{array}
$$

whereas:

$$
\begin{aligned}
& \mathrm{K}_{1}(\alpha)=\left[\mathrm{Z}_{1}(\alpha) \cdot \mathrm{Z}_{3}^{\wedge}(\alpha)-\mathrm{Z}_{1}^{\wedge}(\alpha) \cdot \mathrm{Z}_{3}(\alpha)\right]-\left[\mathrm{Z}_{2}(\alpha) \cdot \mathrm{Z}_{4}^{\wedge}(\alpha)-\mathrm{Z}_{2}^{\wedge}(\alpha) \cdot \mathrm{Z}_{4}(\alpha)\right] \\
& \mathrm{K}_{2}(\alpha)=\left[\mathrm{Z}_{1}(\alpha) \cdot \mathrm{Z}_{4}^{\wedge}(\alpha)-\mathrm{Z}_{1}^{\wedge}(\alpha) \cdot \mathrm{Z}_{4}(\alpha)\right]+\left[\mathrm{Z}_{2}(\alpha) \cdot \mathrm{Z}_{3}^{\wedge}(\alpha)-\mathrm{Z}_{2}^{\wedge}(\alpha) \cdot \mathrm{Z}_{3}(\alpha)\right]
\end{aligned}
$$

The uniformity of the spreading of the ice coat with radius a can be expressed by the relations $\mathbf{q}=\mathrm{Q} / \pi \mathrm{a}^{2}$ or $\mathbf{q}=\mathrm{Q} / \pi \alpha^{2} 1^{2}$

$Z_{1}, Z_{2}$ - functions of real variables, related to the cylindrical functions of the Bessel first type $\mathrm{J} 0$ can be presented in the form of series:

$$
\begin{aligned}
& \mathrm{Z}_{1}(\mathrm{x})=\sum_{r=0}^{\infty}(-1)^{r}\left[\frac{\left(\frac{x}{2}\right)^{2 r}}{2 r !}\right]^{2} \\
& \mathrm{Z}_{2}(\mathrm{x})=\sum_{r=0}^{\infty}(-1)^{r+1}\left[\frac{\left(\frac{x}{2}\right)^{2 r+1}}{2(r+1) !}\right]
\end{aligned}
$$

The functions $Z_{3}(x)$ and $Z_{4}(x)$ can be expressed indirectly using functions: $Z_{1}(x)$ and $\mathrm{Z}_{2}(\mathrm{x})$ they take the form:

$$
\begin{aligned}
& \mathrm{Z}_{3}(\mathrm{x})=\frac{Z_{1}(x)}{2}-\frac{2}{\pi}\left\{\mathrm{R}_{1}(\mathrm{x})+\lg \frac{\gamma^{x}}{2} \mathrm{Z}_{2}(\mathrm{x})\right\} \\
& \mathrm{Z}_{4}(\mathrm{x})=\frac{Z_{2}(x)}{2}-\frac{2}{\pi}\left\{\mathrm{R}_{2}(\mathrm{x})+\lg \frac{\gamma^{x}}{2} \mathrm{Z}_{1}(\mathrm{x})\right\}
\end{aligned}
$$

Changing the radius of the load distribution "a" causes the change of the values of coefficients $\mathrm{C}_{1}-\mathrm{C}_{4}$ in the function $=\alpha=\mathrm{a} / \mathrm{l}$. The calculated values take into account the different wheel layouts in the main leg of the aircraft. For example, selected values of coefficients C1-C4 are shown in Table 2. Using the values of selected coefficients from Table 2 , ice sheet deflections were calculated for various load distribution areas, the selected results of which are shown in Table 3

Tab. 2. Values of $\mathrm{C}$ coefficients depending on $\alpha$

\begin{tabular}{|c|c|c|c|c|c|}
\hline $\begin{array}{c}\text { Radius of load } \\
\text { distribution "a" in }[\mathrm{m}]\end{array}$ & $\begin{array}{c}\text { Coefficient } \\
\alpha=\mathrm{a} / \mathrm{l}\end{array}$ & $\mathrm{C}_{1}$ & $\mathrm{C}_{2}$ & $\mathrm{C}_{3}$ & $\mathrm{C}_{4}$ \\
\hline 0,125 & 0,024 & $-0,9997$ & 0,0007 & 0,0004 & 0,0000 \\
\hline 1,0 & 0,019 & $-0,9862$ & 0,0399 & 0,0279 & 0,0001 \\
\hline 1,10 & 0,200 & $-0,9845$ & 0,0445 & 0,0314 & 0,0001 \\
\hline
\end{tabular}




\begin{tabular}{|c|l|l|l|l|l|}
\hline 1,50 & 0,260 & $-0,9701$ & 0,0741 & 0,0615 & 0,0007 \\
\hline 2,08 & 0,390 & $-0,9438$ & 0,1195 & 0,1191 & 0,0024 \\
\hline 5,00 & 0,940 & $-0,7190$ & 0,3375 & 0,7057 & 0,0797 \\
\hline 10,00 & 1,900 & $-0,2549$ & 0,4467 & 2,6444 & 1,2651 \\
\hline
\end{tabular}

Tab. 3. Ice deflection for various load distribution surfaces

\begin{tabular}{|c|c|c|c|c|c|c|}
\hline $\begin{array}{c}\text { Distances } \\
\text { "r" from } \\
\text { the center } \\
\text { of the } \\
\text { load in } \\
{[\mathrm{m}]}\end{array}$ & \multicolumn{5}{|l|}{ Rows of ice coating in [m] for different magnitudes of the load distribution "a" } \\
\cline { 2 - 7 } & 0,125 & 1,0 & 1,5 & 2,08 & 5,0 & 10,0 \\
\hline 0 & 0,0045 & 0,0043 & 0,0042 & 0,0041 & 0,0036 & 0,0024 \\
\hline 0,125 & 0,0045 & - & - & - & - & - \\
\hline 1,0 & 0,0044 & 0,0042 & 0,0041 & 0,0041 & 0,0036 & 0,0024 \\
\hline 1,5 & 0,0043 & 0,0041 & 0,0041 & 0,0039 & 0,0035 & 0,0024 \\
\hline 2,0 & 0,0041 & 0,0039 & 0,0039 & 0,0038 & 0,0034 & 0,0023 \\
\hline 4,0 & 0,0031 & 0,0031 & 0,0033 & 0,0032 & 0,0030 & 0,0022 \\
\hline
\end{tabular}

Calculation of forces in the case of a central deflection

Considering the case of a symmetrical load, the following types of interactions occur in the ice coating: bending moments $\mathbf{M}_{\mathbf{r}}$ and $\mathbf{M}_{\mathbf{t}}$ and shearing force $\mathbf{T}_{\mathbf{r}}$, which operates in a bandwidth of 1 . The expressions for these interactions are as follows

$$
\begin{aligned}
& \mathrm{M}_{\mathrm{r}}=-1^{4}\left[\frac{d^{2} w}{d r^{2}}+\frac{\mu}{r} \frac{d w}{d r}\right] \\
& \mathrm{M}_{\mathrm{t}}=-1^{4}\left[\frac{1}{r} \frac{d w}{d r}+\mu \frac{d^{2} w}{d r}\right. \\
& \mathrm{T}_{\mathrm{r}}=1^{4}\left[\frac{d^{3} w}{d r^{3}}+\frac{1}{r} \frac{d^{2} w}{d r^{2}}-\frac{1}{r^{2}} \frac{d w}{d r}\right.
\end{aligned}
$$

where:

1 - according to the formula (4).

It should be borne in mind that with a large $\mathbf{r}$, i.e. a considerable distance from the place where the load is applied, these expressions are identical to expressions for forces occurring in straight beams. Replacing in the equations (13) the expressions " $\mathrm{w}$ " and derivatives by the function's "Z" are obtained:

$$
\begin{aligned}
& \mathrm{M}_{\mathrm{r}}(\mathrm{x})=-\mathrm{q} 1^{2}\left\{\mathrm{C}_{1}\left[\mathrm{Z}_{2}(\mathrm{x})-(1-\mu) \frac{Z_{1}^{\wedge}(x)}{x}\right]-\mathrm{C}_{2}\left[\mathrm{Z}_{1}(\mathrm{x})+(1-\mu) \frac{Z_{2}^{\wedge}(x)}{x}\right]+\right. \\
& \left.+\mathrm{C}_{3}\left[\mathrm{Z}_{4}(\mathrm{x})-(1-\mu) \frac{Z_{3}^{\wedge}(x)}{x}\right]-\mathrm{C}_{4}\left[\mathrm{Z}_{3}+(1-\mu) \frac{Z_{4}^{\wedge}(x)}{x}\right]\right\} \\
& \mathrm{M}_{\mathrm{t}}(\mathrm{x})=\mathrm{q}^{2} \mu\left\{\mathrm{C}_{1}\left[\mathrm{Z}_{2}(\mathrm{x})+\left(\frac{1}{\mu}-1\right) \frac{Z_{1}(x)}{x}\right]-\mathrm{C}_{2}\left[\mathrm{Z}_{1}(\mathrm{x})-\left(\frac{1}{\mu}-1\right) \frac{Z_{2}^{\wedge}(x)}{x}\right]+\right.
\end{aligned}
$$




$$
\begin{aligned}
& +\mathrm{C}_{3}\left[\mathrm{Z}_{4}(\mathrm{x})+\left(\frac{1}{\mu}-1\right) \frac{Z_{3}^{\wedge}(x)}{x}\right]+\mathrm{C}_{4}\left[\mathrm{Z}_{3}(\mathrm{x})-\left(\frac{1}{\mu}-1\right) \frac{Z_{4}^{\wedge}(x)}{x}\right. \\
& \mathrm{T}_{\mathrm{r}}(\mathrm{x})=\mathrm{q} 1\left\{\mathrm{C}_{1} \mathrm{Z}_{2}^{\wedge}(\mathrm{x})-\mathrm{C}_{2} \mathrm{Z}_{1}^{\wedge}(\mathrm{x})+\mathrm{C}_{3} \mathrm{Z}_{4}^{\wedge}(\mathrm{x})-\mathrm{C}_{4} \mathrm{Z}_{3}^{\wedge}(\mathrm{x})\right.
\end{aligned}
$$

Ice deflection lines at different radii of the load distribution surface are shown in Fig. 1. By introducing to the equations (16) the determined coefficients $\mathrm{C}_{1}-\mathrm{C}_{4}$ and bearing in mind the conditions of the load distribution, one can formulate the equations of moments and shear forces for these cases:

- for the internal area when $(x \leq a)$ :

$M_{r}^{w}(\mathrm{x}, \mathrm{a})=\mathrm{Q}^{2} / \pi \mathrm{a}^{2}\left\{\mathrm{C}_{1}(\alpha)\left[\mathrm{Z}_{2}(\mathrm{x})-(1-\mu) \frac{Z_{1}^{\wedge}(x)}{x}\right]-\mathrm{C}_{2}(\alpha)\left[\mathrm{Z}_{1}(\mathrm{x})+(1-\mu) \frac{Z_{2}^{\wedge}(x)}{x}\right]\right\}$

$\mathrm{M}_{t}^{w}(\mathrm{x}, \mathrm{a})=\mathrm{Q}^{2} \mu / \pi \mathrm{a}^{2}\left\{\mathrm{C}_{1}(\alpha)\left[\mathrm{Z}_{2}(\mathrm{x})+\left(\frac{1}{\mu}-1\right) \frac{Z_{1}^{\wedge}(x)}{x}\right]-\mathrm{C}_{2}(\alpha)\left[\mathrm{Z}_{1}(\mathrm{x})-\left(\frac{1}{\mu}-1\right) \frac{Z_{2}^{\wedge}(x)}{x}\right]\right\}$

$\mathrm{T}_{r}^{w}(\mathrm{x}, \mathrm{a})=\mathrm{Q}^{2} / \pi \mathrm{a}^{2}\left\{\mathrm{C}_{1}(\alpha) \mathrm{Z}_{2}^{\wedge}(\mathrm{x})-\mathrm{C}_{2}(\alpha) \mathrm{Z}_{1}^{\wedge}(\mathrm{x})\right\}$

- for the outer area when $(x \geq a)$ :

$\mathrm{M}_{r}^{z}(\mathrm{x}, \mathrm{a})=\mathrm{Q}^{2} / \pi \mathrm{a}^{2}\left\{\mathrm{C}_{3}(\alpha)\left[\mathrm{Z}_{4}(\mathrm{x})-(1-\mu) \frac{Z_{3}^{\wedge}(x)}{x}\right]-\mathrm{C}_{4}(\alpha)\left[\mathrm{Z}_{3}(\mathrm{x})+(1-\mu) \frac{Z_{4}^{\wedge}(x)}{x}\right]\right\}$

$\mathrm{M}_{t}^{z}(\mathrm{x}, \mathrm{a})=\mathrm{Q}^{2} \mu / \pi \mathrm{a}^{2}\left\{\mathrm{C}_{3}(\alpha)\left[\mathrm{Z}_{4}(\mathrm{x})+\left(\frac{1}{\mu}-1\right) \frac{Z_{3}^{\wedge}(x)}{x}\right]-\mathrm{C}_{4}(\alpha)\left[\mathrm{Z}_{3}(\mathrm{x})\left(\frac{1}{\mu}-1\right) \frac{Z_{4}^{\wedge}(x)}{x}\right]\right\}$

$\mathrm{T}_{r}^{z}(\mathrm{x}, \mathrm{a})=\mathrm{Ql}^{2} / \pi \mathrm{a}^{2}\left[\mathrm{C}_{2}(\alpha) \mathrm{Z}_{4}^{\wedge}(\mathrm{x})-\mathrm{C}_{4}(\alpha) \mathrm{Z}_{3}^{\wedge}(\mathrm{x})\right.$

Assuming that $\mathrm{x}=\mathrm{a}$ and $\mathrm{r}=\mathrm{a}$, we get:

$\mathrm{M}_{r}^{w}(\mathrm{a}, \mathrm{a})=\mathrm{M}_{r}^{z}(\mathrm{a}, \mathrm{a}), \quad \mathrm{M}_{r}^{w}(\mathrm{a}, \mathrm{a})=\mathrm{M}_{t}^{z}(\mathrm{a}, \mathrm{a}), \quad \mathrm{T}_{r}^{w}(\mathrm{a}, \mathrm{a})=\mathrm{T}_{r}^{z}(\mathrm{a}, \mathrm{a})$

\section{Increasing the load capacity of the ice sheets}

If the load capacity of the ice coating is not sufficient, it is possible to increase this load capacity, this can be done by:

- increasing the thickness of the ice coating,

- ice reinforcement.

The choice of the method depends on local conditions, including, but not limited to air temperature, the thickness of the existing ice coating and others. The easiest way to do this is to clean the upper surface of the ice (snow from the surface), which speeds up the natural freezing process and the build-up of ice thickness from the bottom. However, this method requires a longer amount of time. In a shorter time, the strengthening effect can be obtained by pouring the existing ice layer with water layers from 5.0 to $10.0 \mathrm{~cm}$, however, the ambient temperature cannot be lower than $8^{\circ} \mathrm{C}$, and the strength of this layer is lower by about $30 \%$ than the strength of natural transparent ice. 


\section{Conclusions}

Conducted tests in "in situ" conditions on the national water reservoirs allow stating that there is a possibility of using negative ice temperatures in specific conditions under conditions and piston propelled airplanes, which gives the opportunity to increase the operational capabilities of the Armed Forces under extreme conditions threats.

\section{Source materials}

[1] Dejrugin K.K., Karelin D.B. Ledowzje nabludienij na moriach. Leningrad, 1954.

[2] Gorecki Ł.J., Borodacz A.J. Projektirowanije i stroitielstwo wiertoletnych stancji. Jzd.Liter. po stroitielstwu. Moskwa, 1964.

[3] Hertz H. Uber das Gleich gewicht, schwimmender elastischer Platten, Wied. Ann. Phys-Chemie, 1884.

[4] Kaźmierczyk F. Ustalenie możliwości i warunków wykorzystania krajowych pokryw lodowych na jeziorach do startów, lądowań i postoju samolotów" Praca doktorska Wydział Inżynierii Lądowej Politechniki Warszawskiej. Warszawa, 1975.

[5] Korunow M.M. Rasczet ledjanych perepraw. Goslestiechizdat, 1940.

[6] Ławrow W.W. Deformacja i procznost lda. Leningrad, 1969.

[7] Meyerhof G.G. Bearing Capacity of Floating Ice Sheets. J. of the Eng. Mech. Div. Proceedings of A.M. Soc. of Civ.Eng. 1960.

[8] Pinegin W.P. Ob. izmienienijach modulia uprugosti i koeficjenta Poissona $u$ riecznowo lda pri zżatije. Nauka i Technika, nr.3-4, 1927.

[9] Westergard H.M."Stresses in Concrete Runways of Airports “ Proceedings 19 th Doc. 1939.

[10] Zubow N.N. Ldy Arktyki. Izdanije Gławsowmoruti, 1945. 